\title{
NANOTECHNOLOGICAL RISKS AND THEIR INTERNATIONAL AND NATIONAL REGULATION: ITS IMPORTANCE IN THE CONTEXT OF TIME AND HUMAN RIGHTS
}

\author{
RISCOS NANOTECNOLÓGICOS E SEU REGULAMENTO \\ INTERNACIONAL E NACIONAL: SUA IMPORTÂNCIA NO \\ CONTEXTO DO TEMPO E DOS DIREITOS HUMANOS
}

\section{JULIANE ALTMANN BERWIG}

PhD student of Law at Universidade do Vale do Rio dos Sinos with a scholarship from the Coordination for the Improvement of Higher Education Personnel (Coordenação de Aperfeiçoamento de Pessoal de Nível Superior - Capes) through the Program of Academic Excellence (Programa de Excelência Acadêmica - Proex). Master's degree of Law from Universidade do Vale do Rio dos Sinos, specialist in National and International Environmental Law from Universidade Federal do Estado do Rio Grande do Sul and bachelor in Law from Universidade de Santa Cruz do Sul. Professor at the Law School of Universidade FEEVALE. Researcher in the field of the Environment focusing on Theory of Risk and Nanotechnology. President of the Association of Lawyers for Corporate Environmental Law of Rio Grande do Sul (Associação Gaúcha dos Advogados de Direito Ambiental Empresarial - AGAAE). Member of the Board of the Study Groups of the Association of Lawyers for Corporate Real Estate Law of Rio Grande do Sul (Associação Gaúcha dos Advogados do Direito Imobiliário Empresarial - AGADIE) and of the Roessler Movement for Environmental Protection in Novo Hamburgo/RS. Author of the book Direito dos Desastres na Exploração Offshore do Petróleo. Partner/Owner of the Berwig Law Office. 


\title{
WILSON ENGELMANN
}

$\mathrm{PhD}$ and Master's degree in Public Law from the Graduate Studies Program in Law at Universidade do Vale do Rio dos Sinos - UNISINOS, state of Rio Grande do Sul, Brazil; Professor in the same Program for the activities "Legal Transformations of Private Relations" (Master's degree) and "The Challenges of Contemporary Transformations of Private Law" (PhD). Executive Coordinator of the Professional Master's Course in Corporate and Business Law at Unisinos; Leader of the JUSNANO Research Group (CNPq); Productivity Research Fellow of CNPq. E-mail: wengelmann@unisinos.br.

\begin{abstract}
Objective: The present article aims to discuss the risks inherent the new technologies, especially nanotechnology, to the environment and, consequently, to human beings. From this point of view, it presents the evidence of risks pointed out by scholars as well as the discussions already performed at an international level considering their necessary and emerging regulation.
\end{abstract}

Methodology: This article uses the methodology of literature survey and a systemicconstructivist framework to approach the risks, in the light of Niklas Luhmann's concept of society of risk to discuss why nanotechnological risks should be taken into account.

Results: The investigation has as conclusion that, despite the clear evidence of risks, so far there has been no regulation aiming at the development of this technology with investments in safety for the purpose of controlling environmental and human risks. Important issues must be taken into account in the national internal development of a "nanolaw".

Contributions: As a contribution, this paper discusses some of the main events already held at an international level focusing on the regulation of nanotechnology for its safe development with regard to the environment and human beings. At these events reports were issued supporting the need to share information and also to enter into an international agreement on safety measures designed to face nanotechnologial risks by implementing risk management.

Keywords: Nanotechnology; risks; human rights; regulation. 


\section{RESUMO}

Objetivo: O presente artigo tem como objetivo discutir os riscos inerentes às novas tecnologias, principalmente a nanotecnologia, ao meio ambiente e, consequentemente, ao ser humano. Sob esse ponto de vista, apresenta evidências de riscos apontados pelos acadêmicos, bem como as discussões já realizadas em âmbito internacional, considerando sua regulamentação necessária e emergente.

Metodologia: Este artigo utiliza a metodologia de pesquisa bibliográfica e uma estrutura sistêmico-construtivista para abordar os riscos, à luz do conceito de sociedade de risco de Niklas Luhmann para discutir por que os riscos nanotecnológicos devem ser levados em consideração.

Resultados: A investigação tem como conclusão que, apesar da clara evidência de riscos, até o momento não há regulamentação voltada ao desenvolvimento dessa tecnologia com investimentos em segurança para fins de controle de riscos ambientais e humanos. Questões importantes devem ser levadas em consideração no desenvolvimento interno nacional de uma "nanolaw".

Contribuição: Como contribuição, este artigo discute alguns dos principais eventos já realizados em âmbito internacional, com foco na regulamentação da nanotecnologia para seu desenvolvimento seguro em relação ao meio ambiente e aos seres humanos. Nesses eventos, foram emitidos relatórios de apoio à necessidade de compartilhar informações e também de um acordo internacional sobre medidas de segurança projetadas para enfrentar riscos nanotecnológicos através da implementação do gerenciamento de riscos.

Palavras-chave: Nanotecnologia; riscos; direitos humanos; regulamento.

\section{INTRODUCTION}

Nanotechnology, discovered a few decades ago, is gradually becoming part of various products in the everyday life of society. Since 1959, when Richard Feynman mentioned the new technology, there has been a great evolution in the possibilities of applying it, but so far little is known about its short, medium and long term effects on the environment and on human beings. What is known is that this technology is surprising and may revolutionize the way in which society is organized, making many processes easier. However, just as at the time of the Industrial Revolution, it is not known which and how will be its consequences. 
The national and international dialogue on nanotechnology is guided by these uncertainties. There are many requirements regarding the need to regulate it. But at the same time many other questions arise as to how this regulation should be performed in order to simultaneously promote the development and the safety of the environment and of human beings. This is a problem that has to be dealt with; in other words, regulation is an essential measure in the face of the possible risks and the need to develop this technology.

For this purpose this article uses the methodology of literature survey and a systemic-constructivist framework to approach the risks, in the light of Niklas Luhmann's concept of society of risk, and, based on these, to discuss why nanotechnological risks should be taken into account. It also tries to recover the lessons that can be learned from big technological - although not nanotechnological - disasters that had serious negative effects in their varied possibilities and that persist to the present day. Although, as mentioned, they were not nanotechnological, these disasters have a necessary resemblance which must be realized by the scientific community: risks.

As a hypothesis to solve the problem presented, we shall begin with an international approach based initially on human rights, by means of a convention to be signed between the conciliating countries, thus aiming at elaborating an international regulation and its subsequent internalization on a national level.

This, the article discusses some of the main events already held at an international level focusing on the regulation of nanotechnology for its safe development with regards to the environment and human beings. At these events reports were issued supporting the need to share information and also to enter into an international agreement on safety measures designed to face nanotechnologial risks by implementing risk management.

Despite these discussions, as the reasoning proceeds, it will be demonstrated that, faced with the change in the paradigm of responsibility for these nanotechnological risks - since they are not individual, but collective, environmental and transtemporal -, it is necessary to have an equal evolution. In other words, there 
is a scientific dearth of contextual and systemic view on the effects that can be generated by nanotechnology. This an ethical approach founded on human rights is essential.

At the end of the article, having fulfilled all stages of the demonstration of risks, international discussions and a necessary foundation of human rights, some nuances will be dealt with regarding how the internal legislation can be designed to control the risks and, at the same time, promote the development of nanotechnology connected to its temporal evolution.

\section{NANOTECHNOLOGICAL RISKS AND THE NECESSARY REGULATION}

Nanotechnology opens up the frontiers to a "world" of innovative possibilities in many different fields such as medicine, safety, cosmetics, household appliances, among many others. Although it has not been much disseminated, the nanoworld is already in the market, despite the fact that little is known about it, its possibilities for advances and limitations, its benefits and it's not expected but possible damage to the environment and to human beings.

It has been estimated that approximately 2,000 (two thousand) products that incorporate nanotechnology are already being sold (SHEARER, 2017), and this number may be even greater given the absence of regulation and control. Outstanding among these are the sectors of energy, agriculture and livestock, water treatment and remediation, ceramics and coatings, composite materials, plastics and polymers, cosmetics, aerospace, naval and automotive sectors, steel industry, dentistry, textiles, cement and concrete, microelectronics, diagnosis and prevention of diseases and targeting systems for medications (ENGELMANN, 2012, p.4).

Nanoscience can be defined as the "field of knowledge that studies the fundamental principles of molecules and structures, in which at least one of the dimensions is between about 1 and 100 nanometers. A nanometer (abbreviated $\mathrm{nm}$ ) is the billionth part of the meter, i.e. $10-9$ of a meter, namely: the number 
$1 / 1,000,000,000$, or else: $0.000000001 \mathrm{~m}$, or the nanometer is nine orders of magnitude smaller than the meter. Hence, nanotechnology means to apply these nanostructures to usable nanoscale devices" (ALVES, 2004, p.30-31).

According to Pyrrhoi and Schramm:

\begin{abstract}
Nanotechnology is a set of technical and practical knowledges, techniques and practices that study and explore the new properties of the materials when manipulated at atomic and molecular levels. The technical possibility of organizing and controlling matter, beginning with its smallest dimensions and units, can imply profound transformations in the industrial process of production and have morally significant consequences on human interrelationships, the organization of the prevailing social conjuncture and the phenomenon of life itself as a whole (PYRRHOI, 2012).
\end{abstract}

The purpose of nanotechnology is to bring more efficiency to the production and use of nanomaterials, be it in the automotive industry with lighter and more resistant materials, in communications, speeding up data transmission and storage, in chemistry, resulting in greater energy efficiency, in pharmaceutics with medication diffusion systems that reach specific points in the human body, in the energy sector with an ecologically-sound storage and production of energy, or in the environment with materials that allow removing pollutants from industrial effluents, and also their protection when disasters occur. Nanotechnology can be employed in different fields, always with the main objective of "more efficiency" and "new solutions". Moreover, different types of nanomaterials are discovered every day, and since they make it possible to have more efficient, lighter, more adequate and especially low cost end products, many of them are already being sold in cosmetics, home appliances, clothing and in various utensils and pieces of equipment (ALVES, 2004, p.30-31).

The attention of the "academia" is driven to the fact that in less than a decade nanotechnology developed exponentially, even considering the obscurity of its properties in the narrow scientific, economic and public field (ABBOTT; MARCHANT; SYLVESTER, 2009). The effective adoption of regulations turned specifically to nanotechnology is increasingly difficult. Governments invest strongly in R\&D programs, but are not enthusiastic about the need to implement a regulatory program (ABBOTT; MARCHANT; SYLVESTER, 2009). 
The effects of nanotechnology will be obviously determined in the specific applications, which requires improved and detailed knowledge. Some of them may be dangerous, others impressively beneficial, or also useless. However, there is no doubt that many people feel the need to do something now, in order to avoid apocalyptic scenarios, speed up a nano-paradise, or seek a path, even if this is in "Soft Law" (SYLVESTER; ABBOTT; MARCHANT, 2009).

The key, of course, should start from its origin, i.e. the construction of a consensus around the science. The desired unanimity is possible, but begins with a scientific agreement concerning the risks and benefits of this very new technology (SYLVESTER; ABBOTT; MARCHANT, 2009). However, what is perceived by the scholars working with regulation is that the impasse that is being faced lies in the condition of a "novel risk" and all uncertainties regarding the limits of the potential problems as opposed to the advantages, the dose-effect relations, the options for risk reduction vis-à-vis the costs and the magnitude of their negative consequences (vlek, 2009).

Similarly, other questions related to the risks have already been the subject of international discussion: bioterrorist threats (botulinum in milk), the release of pathogenic organisms or biotoxins into the water supply. Furthermore, regarding nanotechnology present and future risks require large amounts of information and capacity for detection by an information technology system (FAUNCE, 2009, p.629642). The responses to the threats, unexpectedly virulent modifications, such as the influenza virus (similar to the strain that caused the Spanish flu pandemic in 19181919 and killed up to 50 million people worldwide), will probably benefit from nanotechnology through a surveillance system. This and many other factors illuminated the need to develop the innovative technologies (particularly nanotechnology) that can allow health professionals and professionals in other areas to quickly detect small amounts of local viral loads with an ample capacity for dispersion (FAUNCE, 2009, p.629-642).

However, the contrary is also quite possible, since the limits and damaging effects are unknown, and also a malevolent promotion of nanotechnology can be 
occasioned and pursued by governments due to the political and economic conflicts on the international scene. The world has already had many examples of this. The nuclear bomb that devastated Hiroshima and Nagasaki in Japan was initially developed by Albert Einstein aiming at the positive effects of the technology: a small quantity of matter would be the equivalent to a huge quantity of energy. But the technology was used for an evil purpose because of the American ambition for victory in the Second World War (CIÊNCIA HOJE, 2017).

In 1939, Albert Einstein wrote a letter to President of the United States, Franklin Roosevelt, talking about the bomb and its destructive power. This capacity was due to the nuclear chain reaction triggered by a large mass of uranium. The letter was to draw attention to the fact that Germany had the knowledge to develop this type of technology, which was a real threat in the context of the Second World War. The weapon was developed and had disastrous consequences. But a few years later, Einstein expressed his regrets. "I made one great mistake in my life - when I signed the letter to President Roosevelt recommending that atom bombs be made" (CIÊNCIA HOJE, 2017).

Other examples are the technological flaws that gave rise to various accidents and disasters worldwide when the only concern was the capacity for economic production and not the implicit risks. In the Gulf of Mexico millions of liters of oil were discharged into the sea in 2010 with devastating effects on the marine habitat, besides the economic loss to fishing, tourism and the real estate business. In 2011, Fukushima, submerged by the giant waves generated by the earthquake with an 8.9 magnitude on the Richter scale, faced the invisible enemy, radiation, after the failure to switch off one of its nuclear power stations (BERWIG; ENGELMANN, 2017, p.615-634).

Considering these disasters (Fukushima, Gulf of Mexico and Mariana), and so many others that have already occurred on the most variable scales, one can see that the distributed damage and risks are not limited to the site of the industrial activity and to that particular time, as they easily spread out in space and in time. Thus the new technologies were developed and, although various problems were 
solved, new "unknown" ones were created. "They were called 'risks', which became an intrinsic component of post-industrial society, a society marked by the distribution of wealth, but also of many risks with consequences that surpassed the limits of what could be imagined, with transtemporal, transterritorial and transgenerational effects" (BERWIG, ENGELMANN, 2017, p.615-634).

One can see that technologies, "at the same time that they create prospects of improving human life, may also have nefarious effects". Techniques that aimed at improvement produced negative effects (BARRETO, 2008, p.1016). This possibility of effects involves "risks" that may have either a positive or a negative result.

So far there has not been any news of an environmental disaster caused by nanotechnology. The chemical elements found are known, but their properties on a nanoscale make them qualitatively different. In the environment, the effects are related to the nanomaterials due to their greater permeability, dispersion capacity, persistence, adsorption and potential to be transformed or interact with other contaminants that can have effects on the aquatic and terrestrial ecosystems when released into the environment. Thus, on a nano scale, the physicochemical characteristics tend to undergo modifications that may even generate toxic effects. At this point the pressing issue of undesirable effects must be emphasized, many of which are as yet completely unknown (FIORINO, 2010).

The environmental damage that may result from nanomaterials is related, for instance, to the fact that the time of residence of nanoparticles and their aggregates in the air may be different from most of the other dust particles on a micrometric scale. Moreover, the oxidation and dissolution rates, which are highly dependent on the surface area, may increase dramatically when the size becomes smaller, potentially releasing constituent materials in a bioavailable format (GUZMÁN; TAYLOR; BANFIELD, 2006). ${ }^{1}$

There is also a great concern regarding the effects of carbon-based nanomaterials, considering the forecasts that they may be strongly dispersed into the cellular hydrophobic compounds, such as lipids, in relation to water, resulting in a

1 l.e. that can be absorbed by organisms. 
potentially significant bioconcentration. On a global scale, the nanoparticles should also be considered, such as regarding those in the atmosphere, inducing organic transformations, reactions and many others that are as yet unknown (GUZMÁN; TAYLOR; BANFIELD, 2006).

Considering the magnitude, lack of knowledge and complexity of the systemic effects of the nanotechnological risks, since they have the power to reach a large part of a society, as well as the environment, the development of a legal guide for nanotechnology is extremely necessary.

The purpose now is not to stop development, but rather to contribute to the development founded on risk management, in order to avoid the disasters that society has already undergone. Current society is no longer the same as that of the Second World War, as it is a risk society. Luhmann explains, in this sense, that society presents the characteristics of a system, enabling the understanding of the social phenomena via the bonds of interdependence that unite them and constitute them into a totality (ROCHA, 2007, p.51).

The modernization process has rendered the social system even more complex and multifaceted, and it is no longer capable of controlling itself. The process is, then, applied to itself, since society lives under the absolute control of the modernization of industry (DE GIORGI, 1774, p.45-54). Therefore, risk society began when the flaws began to appear in the systems of social rules that promised safety, due to the lack of capacity to control the menaces that come from decisions made with regard to new challenges. There are diverse menaces, of an ecological, technological, political nature, among others, and the decisions are the results of coercions that derive from the economic rationality that imposes the model of universal rationality (DE GIORGI, 1994, p.45-54)

In this modern society, not only wealth is distributed, but many risks, in other words, systemic risks resulting from the failures/lack of observance of the subsystems in relation to the new forms of development (LUHMANN, 2005, p.144). Thus, like the great social inequalities, the absence of parameters of ethical responsibility may cause a loss without precedent to the planet. The legal omission 
shows the unpreparedness of society towards the reality of technoscience and its impacts (ENGELMANN, WILLIG, 2016, p.207). Despite the many things learned, there is still a way of thinking focused on the immediate result of the innovation provided by the new technologies and not on the future of human beings and the environment. Obviously the protection against environmental impacts goes in the same direction as the protection of human beings, because there is no doubt that the destruction of the environment, or at least an inhospitable environment, will not sustain and support human life (ENGELMANN, WILLIG, 2016 ,p.210). Now, it is known that human beings are beings-in-the-world integrated into the global reality that surrounds them, and the deterioration of the natural surroundings seriously affects their own personal structure. The vulnerability of nature to suffering damage reminds one of the vulnerability of human beings themselves (JUNGES, 2004, p.68$69)$.

Accelerated technological development does have many advantages, but fascination at them generates the blindness and forgetfulness regarding prevention and precaution against environmental damage and, consequently, damage to humans. In this sense, the insertion into the nano world opens up the possibility of constructing new identities, new spaces, with unknown magnitudes. Concerns and ambiguities that are specific to humans arise, as well as the need to face problems through practical reason. There is an emphasis on the need to create conditions to assess the positive and negative aspects, aiming at risk management while maintaining the environment and, consequently, life (ENGELMANN, 2011, p.297366).

Danger indeed increases in the current reality of technoscience. The new technologies' power of intervention attains levels never before imagined by human beings. These technologies are capable of achieving scientific and technological developments which solve many problems and contribute to the socioeconomicenvironmental development of society. However, in some situations, they associate solutions with unwanted risks, unplanned side effects, and may thus lead to effects (ENGELMANN; WILLIG, 2016, p.221). that cause irreversible environmental and 
human damage. Thinking focused only on development has already proved to be self-destructive, as shown by the various environmental disasters cited, that were caused by the absence of prevention/precaution in the generation of new technologies.

Ethical responsibility is projected to the decision-making according to the scenario of the occasion and even of the product and risk involved. Thus, "the tradition of the interpreter, of the situation and of the researchers is to be projected onto the historical horizon, thereby learning from past experiences using revolutionary technologies" (ENGELMANN; WILLIG, 2016, p.216).

Therefore, the future depends on decisions (LUHMANN, 1992, p.36). Renouncing risks means - above all under present conditions - to renounce rationality. This is, however, not satisfactory, since damage may or not occur. As the future is uncertain, what is done now may in future present desirable or undesirable results (LUHMANN, 1992, p.57-59).

However, although there are doubts about the efficacy of government regulation in controlling nanotechnological risks, there is no doubt that the public's reaction in a disaster involving nanotechnology would be much worse than in those that have already occurred. Moreover, the non-regulation would show the guilt of governments because they allowed this development and, consequently, the disaster (ABBOTT; MARCHANT; SYLVESTER, 2009).

Who should regulate nanotechnology? Because of the international reach of technology, one way to do it would be to begin with a transnational action aiming to coordinate/harmonize the national rules (ABBOTT; MARCHANT; SYLVESTER, 2009).

From this angle, the rapid appearance of nanotechnology provides an opportunity for a different approach. With nanotechnology, advocates of policies, academics and government officials are discussing a possible international coordination before the problems arise, aiming to prevent or at least limit future damage (ABBOTT; MARCHANT; SYLVESTER, 2009) 
The main motor of international coordination is the acknowledgment that trade and development of nanotechnology are of an increasingly global nature and must be approached on this level. Nanotechnology, thus, may represent a new paradigm for regulation in the $21^{\text {st }}$ century - proactive, global regulation, capable of adapting to the rapidly changing conditions (ABBOTT; MARCHANT; SYLVESTER, 2009).

Many considerations support an international approach to the regulation of nanotechnology. Since nanotechnology is so new, it would not be necessary to superimpose international standards on a network of diverse and pre-existing national rules. At the level of products, manufacturers, processors and all vendors will benefit from a single set of regulatory requirements to perform tests, assess risks, make reports, design and labelling (ABBOTT; MARCHANT; SYLVESTER, 2009).

Furthermore, inconsistent national regulations are reflected in distinct technical nomenclatures and standards, which multiplies costs throughout the supply chain, making international cooperation in trade and research development more difficult. At the level of manufacturing, internationally harmonized standards in health and environmental and occupational safety would allow multinational companies to comply with the same standards at a global level. This would provide other efficiencies, enabling the assessment of complex risks, a single determination of technological feasibility, instead of repeated determinations by each of these companies (ABBOTT; MARCHANT; SYLVESTER, 2009).

Harmonized regulations would make international trade easier, preventing the disputes and inefficiencies experienced as a result. Consistent international standards would also protect against an inordinate race in which governments sacrifice public safety or workers to attract researchers or manufacturers to settle within their borders (ABBOTT; MARCHANT; SYLVESTER, 2009).

As a result, harmonization would bring equal protection to the environment, citizens and workers of all nations. The international regulatory coordination is necessary in the light of the well-known fact that the nanomaterials released into the 
environment can cross national borders, negatively affecting other states, the atmosphere and the seas (ABBOTT; MARCHANT; SYLVESTER, 2009).

Considering the explanation of this risk scenario and the need for international regulation in the light of globalization, the question that remains is: How could this international regulation occur, and what would be its founding guide? This is the question that we aim to answer, but before this the main issues that are under discussion at an international level will be pointed out.

\section{THE INTERNATIONAL DIALOGUES FOR A REGULATION OF NANOTECHNOLOGY}

Despite this regulatory absence already commented, it should be mentioned that the topic "nanotechnology" is the object of international meetings. One of them was called together by the Meridian Institute and held in 2004 in the United States, under the title "International Dialogue on Responsible Research and Development of Nanotechnology". The dialogue on the international coordination of research and regulation of nanotechnology occurred between 25 countries. At that meeting, the then director of the White House Office for Scientific and Technological Policies, John Marburger, told the delegates that (ABBOTT; MARCHANT; SYLVESTER, 2009):

If we are to realize the full potential of nanotechnology for our nations, and for the developing nations that can share its benefits, then we are going to have to agree particularly on standards and nomenclature, on issues of intellectual property protections, and on the need for responsible oversight and regulation of hazards that we may discover in these technologies.

At another meeting that took place in 2006 in Japan the discussion concentrated on how to ensure that the research and development programs for nanotechnology be performed in a responsible manner. The participants discussed a wide range of topics, including matters related to regulation and governance, health 
and safety, environment and ethics, and also matters that pertain only to developing countries (MERIDIAN ISTITUTE, 2017).

In 2007 a preparatory meeting was organized to define elements and structure of the third international dialogue, which took place in Cape Town (ZA), under South African chairmanship (CORDIS). In 2008 in Brussels the "Third International Dialogue on Responsible Research and Development of Nanotechnology" took place, with 97 participants representing 49 countries, international organizations, multinational companies, industries and universities. This meeting led to the report that explained the following (CORDIS, 2017):

The final aim of this dialogue is to facilitate good governance in nanotechnology, aiming at a development of nanotechnology that corresponds to the needs of society as a whole, without creating new economic or knowledge disequilibria, whether within or between countries in the world. In this respect this dialogue wants to be inclusive, involving all countries and stakeholders interested in the responsible and sustainable development of nanotechnology.

In September 2014 Brazil joined the "NANoREG" project, which aimed at supplying the regulating agencies and Brazilian lawgivers with the tools needed to regulate nanotechnology based on scientific knowledge, in tune with worldwide regulation, and which will provide safety for workers, consumers and the environment (BRASIL, 2017).

In Brazil, the participating government agencies and institutions were the following (NANOREG, 2015):

\begin{tabular}{|c|c|c|c|}
\hline 72 & CENTRO DE TECNOLOGIAS ESTRATÉGICAS DO NORDESTE & CETENE & \multirow[t]{9}{*}{ Brazil } \\
\hline 73 & EMPRESA BRASILEIRA DE PESQUISA AGROPECUÁRIA & EMBRAPA & \\
\hline 74 & INSTITUTO NACIONAL DE METROLOGIA, QUALIDADE E TECNOLOGIA & INMETRO & \\
\hline 75 & UNIVERSIDADE FEDERAL DO RIO GRANDE DO SUL & UFRGS & \\
\hline 76 & $\begin{array}{l}\text { UNIVERSIDADE DE SÃO PAULO } \\
\text { DEPARTMENT: SISNANO-USP }\end{array}$ & $\begin{array}{l}\text { Gnano IFSC } \\
\text { USP }\end{array}$ & \\
\hline 77 & $\begin{array}{l}\text { UNIVERSIDADE FEDERAL DO RIO GRANDE; } \\
\text { DEPARTMENT: INSTITUTO DE CIÊNCIAS BIOLÓGICAS (ICB) }\end{array}$ & FURG & \\
\hline 78 & $\begin{array}{l}\text { UNIVERSIDADE FEDERAL DE MINAS GERAIS } \\
\text { DEPARTMENT: INSTITUTO DE CIÊNCIAS BIOLÓGICAS (ICB) }\end{array}$ & UFMG & \\
\hline 79 & $\begin{array}{l}\text { UNICAMP - UNIVERSIDADE ESTADUAL DE CAMPINAS; } \\
\text { DEPARTMENTO DE QUÍMICA INORGÂNICA } \\
\text { NANOBIOSS/INSTITUTO DE QUÍMICA }\end{array}$ & NanoBioss & \\
\hline 80 & MINISTÉRIO DE CIÊNCIA, TECNOLOGIA E INOVACÃO & MCTI & \\
\hline
\end{tabular}


This project was an initiative of the European Union and coordinated by the Dutch Ministry of Infrastructure and Environment. More than 85 partners collaborated to develop reliable, reproducible and relevant methods to test and assess the effects of nanomaterials on human health and on the environment in a regulatory context (NANOREG, 2017a). The objective of the project was:

1. Providing legislators with a set of tools for risk assessment and decision making instruments for the short to medium term, by gathering data and performing pilot risk assessment, including exposure monitoring and control, for a selected number of nanomaterials used in products; 2. Developing for the long term new testing strategies adapted to a high number of nanomaterials where many factors can affect their environmental and health impact. 3. Establishing a close collaboration among authorities and industry with regard to the knowledge required for appropriate risk management, and create the basis for common approaches, mutually acceptable datasets and risk management practices (NANOREG, 2017a).

The project which was to last 48 months was finalized on February 28, 2017 (NANOREG, 2017a). When it was finalized, the participants concluded that there is a growing awareness in the community regarding the safe development of nanotechnology, the key to which is collaboration. Without an active exchange of the results obtained in individual projects, including the experimental data, there is a serious risk of having to begin the process all over again from zero (NANOREG, 2015).

Formal and practical hurdles were found in "NANoREG" to access the results of other projects and share them. Thus, in conclusion the report informs that the nanosafety community would gain much if these hurdles could be removed and if measures would be taken to create a solid base for "advanced information management”, comprising: “i) Project results ... accessible and available ...; ii) Assurance of basic quality and comparability of experimental data; III) Uniform language [...]" (NANOREG, 2015).

In this project notes as to how the nanotechnological risks could be managed were developed and the key elements for the analysis of uncertainty were pointed out: 
- A tiered approach should be applied, with the level of detail proportionate to the level of uncertainty and impact of the risk characterization; - It is necessary to distinguish between "uncertainty", which can be reduced, and "variability", which is inherent to the system, and address both; - There are three categories of uncertainty, i.e. scenario, model and parameter uncertainty: "scenario uncertainty" is linked to the uses of the substance; "model uncertainty" is linked to use of extrapolation, parametrisation, and correlation between parameters; and, finally, "parameter uncertainty" is linked to the measurement of the parameter, sampling error, choice of dose descriptors, and extrapolation factors (NANOREG, 2017b).

Uncertainty analysis is organized into three levels: i) Level 1: qualitative uncertainty analysis to refine the exposure estimate and provide an indicative range of unquantifiable uncertainties; ii) Level 2: derivation of a range of point estimates by means of a deterministic approach to describe the extent of uncertainty; iii) Level 3: use of probability distributions to provide statistical information about the likelihood. Thus, it concludes that "Risk characterization for NMs is, as for all chemicals, a combination of exposure and hazard information and the discussion of the related uncertainties" (NANOREG, 2017b).

The risk may be overestimated in some situations, which would render the production chain unfeasible. The documents also present a strategy to prioritize the risk assessment, based on six elements that describe the most important determinants of the process: 1. Exposure potential; 2. Dissolution; 3. Transformation during the life cycle; 4 . Accumulation; 5 . Genotoxicity that may lead to cancer and 6. Immunotoxicity. The result of this process was the figure that shows the way to go (NANOREG, 2017b). 


\section{Figure 1}

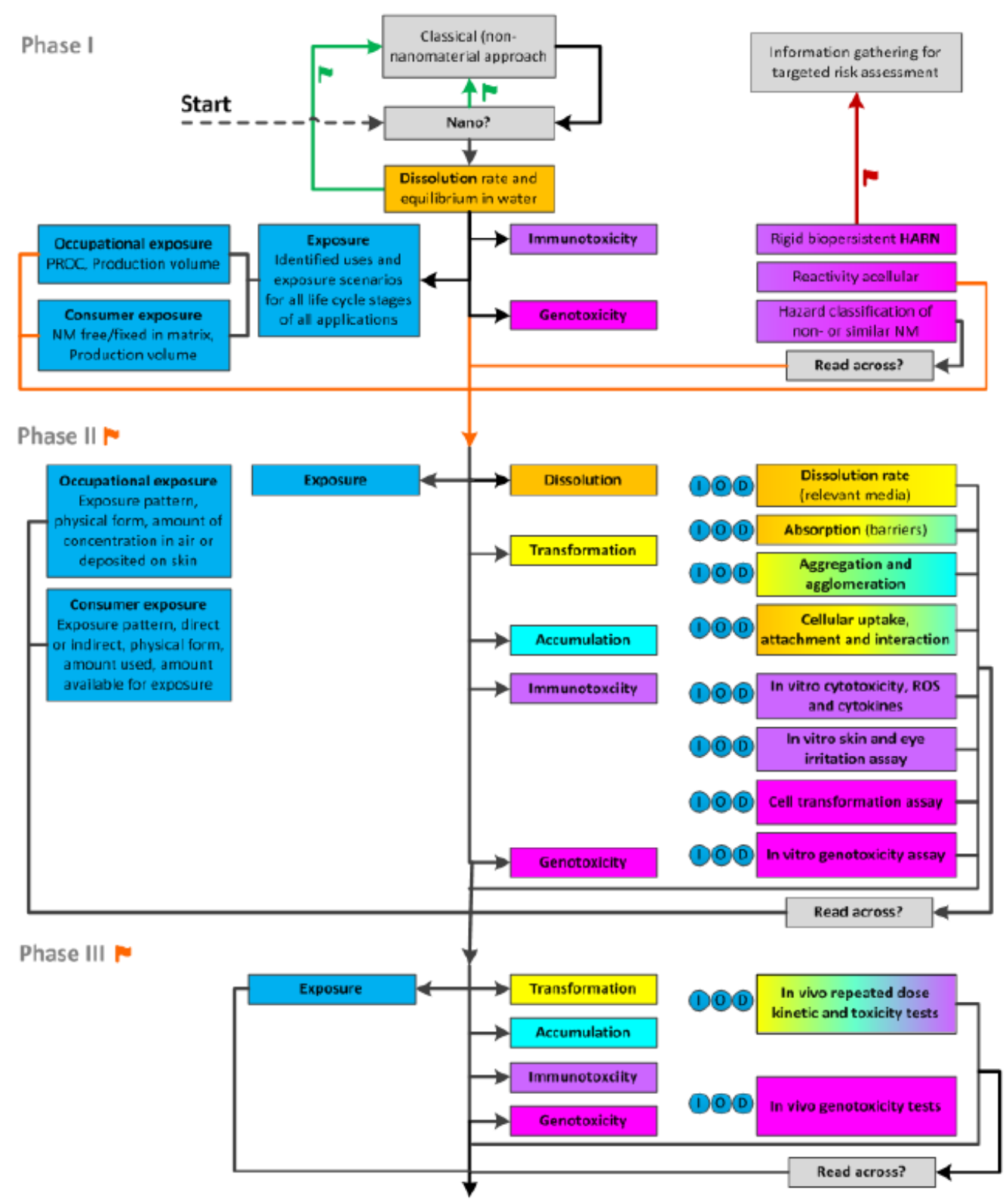

Source: Nanoreg, 2017b. ${ }^{2}$

${ }^{2}$ Figure 1. "Flow chart showing the different phases of the proposed approach towards nanospecific prioritisation and risk assessment. Black arrows: evaluation of the NM following the elements related to kinetics, toxicity and exposure in phase I, II, III and further. Green arrows: the material is not a nanomaterial or has such a high dissolution rate in water that it dissolves into its molecular or ionic form before it reaches its target $->$ the classical (non-nanomaterial) risk assessment can be performed. Red arrows: the material is a 'rigid and biopersistent High Aspect Ratio Nanomaterial (HARN)' $\rightarrow$ substitution or information gathering for targeted risk assessment to evaluate the potential to cause mesothelioma is needed. Orange arrows: the material does not meet the criteria for classical (non- 
The results obtained from the "NanoReg" project, as recorded, are important to contribute to elaborating and instituting the "White Paper Process". The purpose of this paper is to create regulating and innovating recommendations regarding nanotechnology for its efficient development in terms of current and future costs. The consultation procedure for the draft White Paper and the workshop with policymakers and innovators foreseen for autumn 2017 is expected to also contribute to the support for the recommendations (NANOREG, 2015).

It was concluded finally that "To create this advanced information management", a "new initiative or overall programmatic approach, such as the implementation of the EU Framework Programme for Research and Innovation", is necessary (NANOREG, 2015).

In the European Union, despite the discussions, there is already legislation in specific fields that includes a legally binding definition of nanomaterials, namely:

\footnotetext{
- the Cosmetic Products Regulation No 1223/2009; • the Regulation on the Provision of Food Information to Consumers No 1169/2011, - amended by the Regulation No 2015/2283; • the Regulation on Plastic Materials and Articles Intended to Come into Contact with Food (EU) No 10/2011; • the Biocidal Products Regulation No 528/2012 (STONE, 2017).
}

One can see that international discussions about nanotechnology regulation are ongoing, even if taking short steps. Abbott, Marchant and Sylvester suggest that an organization specialized in transnational expertise could further this process, being tasked with periodically evaluating the scientific and technological comprehension of nanotechnology, including information about its risks and benefits, in this way supplying a consistent scientific baseline for national regulation (ABBOTT; MARCHANT; SYLVESTER, 2009). Like the International Organization for Standardization (ISO), an organization could supply useful information and

nanomaterial) risk assessment or targeted risk assessment to evaluate the potential to cause mesothelioma -> use the information from phase I for prioritisation and/or further evaluation following the elements related to kinetics, toxicity and exposure in phase II, III and further. D = Dermal route of exposure; I = Inhalation route of exposure; $\mathrm{NM}=$ nanomaterial; $\mathrm{O}=$ Oral route of exposure; $\mathrm{PROC}=$ Process Category; ROS = Reactive Oxygen Species." 
guidelines, even at the global level, in the absence of formal government regulation (ABBOTT; MARCHANT; SYLVESTER, 2009).

Despite practical difficulties we believe that some form of transnational harmonization of nanotechnological regulation will be considered desirable, sooner or later. In our view, the definition must be as uniform as possible in different global and local legal frameworks, to avoid a material being considered nanomaterial in one structure and not in another (STONE, 2017).

Abbott, Marchant and Sylvester also suggest two models of short and medium term international approach. In the short term, one might begin with informal arrangements designed to increase and share knowledge of nanotechnology, its risks and benefits, and possible forms of regulation. These might include: (1) forums for dialogue among scientists, business firms and national regulators; (2) codes of conduct informed by professional or social responsibility norms; (3) a transnationally designated body of independent experts to monitor progress in nanotechnology along with its social, economic, environmental and other impacts. In the medium term, consider a framework convention which could have multiple dimensions and concerns. The aim of such an agreement would not be to establish strong mandatory regulation; rather, its goals would be to continue promoting research, information sharing and consultation to establish procedures by which the international community could act quickly if a need for more concrete regulation were to arise. The overall aim would be to establish pathways to appropriate regulation by creating opportunities for dialogue and learning, and streamlined procedures, by which regulations can be harmonized and strengthened as necessary to respond to the risks of nanotechnology as they appear over time, while avoiding regulation that is too early, too stringent or simply ill-informed (ABBOTT; MARCHANT; SYLVESTER, 2009).

In the same sense, the authors who elaborated the "European NanoSafety Cluster" believe that the best way for improving and harmonizing the monitoring strategies will be to carry out monitoring surveys and use the data in the context of regulatory risk assessment of NMs. Sharing of raw or processed data as well as 
experiences will also allow an evaluation and comparison of results from monitoring surveys, which will lead to overall, gradual improvements in the monitoring strategies (STONE, 2017).

Concluding this section, one can see that the paths to an international design are proposed in different ways, and all of them prove to be plausible in the face of the regulatory vacuum that generates many insecurities for all those involved, especially when there are already sources and reliable evidence of the possible damaging effects of this fascinating technology when it is not employed in a controlled risk management plan. However, even considering these approaches the issue that remains is that it is necessary to have an argument founded on the supreme protection of the environment and human beings as values in themselves. Through this route, this international regulatory need is connected to human rights in the light of the strong international influence and safety that must be considered.

\section{HUMAN RIGHTS AS THE INTERNATIONAL REGULATORY GUIDE OF NANOTECHNOLOGY}

The daring rise of this very broad and significant technology creates an opportunity for an unprecedented experience in the elaboration of a new regulatory approach (ABBOTT; MARCHANT; SYLVESTER, 2009). This new approach may include, in a new form of legal security, an international safety that will control the possibility of future disastrous events, like those experienced during the Second World War and in the various environmental disasters that damage of which persists in time and space.

Engelmann believes that "there is no other humanly acceptable alternative but returning to the only element that does not change in its essence, namely, the humanness of human beings" (ENGLEMANN, 2010). Therefore, it appears that the great challenge to the theory of responsibility in the technoscientific society is to consider human dignity as a primary category, serving as a principle to answer the 
questions regarding the "type of person we wish to be and what kind of society we intend to build" (BARRETTO, 2008, p.1018).

It is, therefore, necessary to protect humankind and for this reason the ethical parameters that limit human action in connection with technoscience are questioned. The identification of the ethical responsibility is essential, because it enables sustainable (social, economic and environmental) development (ENGELMANN, 2016, p.186).

The new technologies, especially those related to human beings, biotechnologies and genetic engineering, have led to legal and existential insecurity in society, both as regards the efficiency of the legal system (legal security and protection of human dignity) and as regards the very existence of the human species with all its positive and negative dimensions. Thus, one can see that the protection of the dignity of the human person is the foundation that is necessary, but not sufficient to deal with the problems that will accrue from the new technologies. Hence, according to Barreto, it is necessary to reformulate law with respect to responsibility, expanding the latter from only interpersonal relationships to the protection of the species itself, with the guidance of philosophical ethics. It is only by returning to the philosophical and social vision that it will be possible to reframe the responsibility for humanity as a whole involved in the new sciences (BARRETTO, 2008, p.1016)

The ethical issues of the present day transcend the restricted realm of interpersonal relations, since, because of technoscience, they reflect problems found in the spheres of ecology, human nature and the future of the human species (BARRETTO, 2008, p.1016). Today there are harmful effects that, even if they occur in a given country, transcend the frontiers and also the time of the generation affected, and are propagated not only to the current, but also to future generations.

Considering this need and this social context, the bases of the classical theory of legal responsibility are insufficient to respond to the problems of multicultural, pluralistic, democratic society whose backbone is the alliance of science with technology, which has repercussions on all aspects of social life. This is due to the fact that its core are individuals rights, contract and individual property, which are 
no longer enough to respond to the needs of the current technoscientific society (BARRETTO, 2008, p.1011-1016). It should be highlighted that society is now a systemic, risk society. Therefore, in a damaging event it is not possible to identify precisely the actors and victims, only the environmental, social and economic losses.

The "ethical questions about scientific and technical progress, especially in the field of life sciences" are the moral problem of the present day. This problem consists of the clash between two responsibilities i) that of the "good" which obliges to preserve; ii) that of the "better" which encourages the progress and qualitative improvement of human life. Thus, it is necessary to construct a humanistic ethical view that will supply arguments to preserve the rhythm of scientific progress and, at the same time, preserve life, serving as a humanizing element (BARRETTO, 2008, p.1017).

This protection must be founded on a global level, including in the Declaration of Human Rights the necessary caution and safety in the development of nanotechnology, with parameters for the ethical responsibility and the protection of human beings regarding the technological and scientific development (ENGELMANN, 2016, p.189).

We emphasize that human rights always seek to protect natural rights, especially the right to life and human dignity. Therefore, the notion of fundamental rights may be considered the synthesis of natural rights and human rights. Natural rights are the "set of rights inherent to human beings, deserving respect from society, regardless of the existence of a positive law". On the other hand, human rights are those "acknowledged in various international documents", but that already existed previously (ENGELMANN; FLORES; WEYERMÜLLER, 2010, p.28). For this reason, there is concern about human beings and the protection of the basic aspects of their survival and development, which are under the internal responsibility of each State, be it at a national or international level, especially as regards the advances of nanotechnology that must include safety, which is the topic of this article (ENGELMANN, 2010, p.118-119). 
To give a few examples, the 1948 Universal Declaration of Human Rights provides, in Article III, that "Everyone has the right to life, liberty and security of person" (ONU, 2014). The International Covenant on Economic, Social and Cultural Rights of 1966 states that "the recognition of the inherent dignity and of the equal and inalienable rights of all members of the human family is the foundation of freedom, justice and peace in the world", and that "these rights derive from the inherent dignity of the human person" (BRASIL, 1992).

The Declaration on the Use of Scientific and Technological Progress in the Interests of Peace and for the Benefit of Mankind of 1975 determines in Articles 6 and 8 that:

6. All States shall take measures to extend the benefits of science and technology to all strata of the population and to protect them, both socially and materially, from possible harmful effects of the misuse of scientific and technological developments, including their misuse to infringe upon the rights of the individual or of the group, particularly with regard to respect for privacy and the protection of the human personality and its physical and intellectual integrity. 8. All States shall take effective measures, including legislative measures, to prevent and preclude the utilization of scientific and technological achievements to the detriment of human rights and fundamental freedoms and the dignity of the human person (DIREITOS HUMANOS, 1975).

In Article 10 the Universal Declaration on the Human Genome and Human Rights of 1996 provides that:

No research or research applications concerning the human genome, in particular in the fields of biology, genetics and medicine, should prevail over respect for the human rights, fundamental freedoms and human dignity of individuals or, where applicable, of groups of people (UNESCO, 2001).

The Universal Declaration on Bioethics and Human Rights of 2006 gives priority to human beings and the protection of their dignity in issues of ethics of sciences:

Article 1 - 1 . This Declaration addresses ethical issues related to medicine, life sciences and associated technologies as applied to human beings, 


\begin{abstract}
taking into account their social, legal and environmental dimensions. 2. This Declaration is addressed to States. As appropriate and relevant, it also provides guidance to decisions or practices of individuals, groups, communities, institutions and corporations, public and private. Article 2 - [...] (c) to promote respect for human dignity and protect human rights, by ensuring respect for the life of human beings, and fundamental freedoms, consistent with international human rights law; [...] Article 3 - 1. Human dignity, human rights and fundamental freedoms are to be fully respected. 2 . The interests and welfare of the individual should have priority over the sole interest of science or society (UNESCO, 2001).
\end{abstract}

Therefore it is not surprising that many issues have already been the subject of international agreements, which increases the possibility of international regulation, or at least an international harmonization of the regulation, but so far, as shown in the previous section, this has not yet occurred with regards to nanotechnology (ABBOTT; MARCHANT; SYLVESTER, 2009).

It should be highlighted that the international regime of human rights is indivisible: all its rules and application, for instance to the regulation of nanotechnology, must be consistent with the social foundation of respect for human dignity (FAUNCE, 2007, p.629-642).

The Universal Declaration of Human Rights aimed to reflect this historical experience of the suffering that had occurred and to prevent it in the future. Therefore, "suffering is the motivating element, the main element in the discourse on human rights". This is where we find the foundation for the creation of the aforementioned regulatory frameworks in nanotechnology, since the technological advances will bring benefits, and learning must serve as the ethical parameter for regulation in order to avoid the suffering experienced in the past by society (ENGELMANN; FLORES; WEYERMÜLLER, 2010, p.86-87).

Supporting this argument, Hans Jonas says in this sense that the cumulative self-propagation of technological changes in the world ceaselessly surpasses the conditions of each of its contributing acts and takes place amid unprecedented situations, in the face of which lessons learned from human experience are impotent. Cumulation as such, not satisfied with modifying its beginning until disfigurement, may even destroy the fundamental condition of the entire sequence, the presupposition of itself. All this should be included in the will of each single act, if it 
were morally responsible. Traditional ethics considered only non-cumulative behavior. Under these circumstances, knowledge became an overriding duty, with the same magnitude as the causal dimension of our action (JONAS, 1979, p.41). And he continues by saying that

\begin{abstract}
No previous ethics had to consider the global condition of human life and the far-off future, even existence, of the race. Their now being an issue demands, in brief, a new concept of duties and rights, for which previous ethics and metaphysics provide not even the principles, let alone a ready doctrine (JONAS, 1979, p.40).
\end{abstract}

It is practically certain, given the great number and diversity of present and future products and applications of nanotechnology, that some of them will damage health, safety or the environment, if they are not duly managed (ABBOTT; MARCHANT; SYLVESTER, 2009).

The relationship between human beings and the environment likewise requires solidary reciprocity. Both are interdependent and must respect their characteristics and potentials. Human beings must realize that "nature exists to be cared for, since it is essential to human survival" (ENGELMANN, 2010). This relationship, according to Engelmann, "does not always take place in the same way, because human life changes, especially now with the repercussions generated by the nanotechnologies, which require new answers that are up to the unprecedented challenges produced" (ENGELMANN, 2010).

In the light of the information introduced, this section can be concluded by mentioning that natural rights, human rights and fundamental rights are part of the same category of rights, designed to protect human beings considering their preexisting values. In the same sense, the environment is part of the elements needed to maintain human life and therefore it is interpreted in the extension of human rights. For this purpose, considering the high risk of the nanotechnological advances combined with the processes of globalization of their products, nothing could be more coherent than to develop an international agreement for the environmental and human safety with regards to nanotechnology. 
In order to introduce the topic on a national level, the current Federal Constitution, in Art. 219, contains a provision for the promotion of human beings through scientific and technological development, but says nothing about the protection of human beings from the consequences of this development (ENGELMANN; WILLIG, 2016, p.192). On the other hand, an international approach could easily be internalized by Brazil, considering that article $5, \S 2$ ("The rights and guarantees expressed in this Constitution do not exclude others deriving from the regime and from the principles adopted by it, or from the international treaties in which the Federative Republic of Brazil is a party") and $\S 3^{3}$ enable the inclusion of the human rights legislated at an international level in the Brazilian national legal system and in others.

Furthermore, considering the damaging events already experienced by human beings and by the environment, be it from the bombs used in the Second World War or from environmental disasters, a lesson should be learned, since these experiences showed the destructive capacity of the damage, its transtemporality and, especially, in relation to globalization, its transborder characteristic.

All these elements justify the need to elaborate an international agreement on the safety of the advances in research, development, manufacturing, trading and final environmentally adequate disposal of the products that contain nanotechnology.

\section{THE REGULATORY INTERNALIZATION OF CONTEXTUAL NANOTECHNOLOGY}

For the internal regulation of nanotechnology, as regards control of safety throughout the production chain, it is important to be aware of two main questions: i) it is necessary to control and at the same time facilitate the development of the technology that will provide many benefits to society; (BROWNSWORD; YEUNG,

\footnotetext{
3 "Paragraph 3. The international treaties and conventions on Human Rights which are approved, in each House of National Congress, in two rounds, by three fifths of votes of the respective members, will be equivalent to Constitutional Amendments."
} 
2008) ii) this control must be as dynamic as the evolutionary movement induced by nanotechnology, and therefore there must be regulation, but somehow it should be capable of being updated every time new solutions or problems are discovered (BENNETT MOSES, 2013).

The power aroused by nanotechnologies requires urgency for its installation, but does not provide the necessary support to a profound discussion on the directions, limits and possibilities of research. This is because scientific knowledge, as mentioned in the previous chapter, is disconnected from this social reality. Scientists develop their experiments without connecting them to the everyday world where they live (ENGELMANN, 2010) Much of this is triggered by the fascination exerted by the new technologies and the economic support that they receive for their development. However, this incentive should involve both sides of the coin, viz. development and environmental and human safety.

The central

challenge

of

regulation

involves reconciling the traditional ideal of regulatory certainty with the generic challenge of keeping the regulatory connection (BROWNSWORD; YEUNG, 2008) with the dynamicity of technology. "The challenge of regulatory connection is an ongoing one, and we need good mechanisms for making ongoing adaptations as circumstances change" (BENNETT MOSES, 2013).

The European NanoSafety Cluster, in this sense through several authors worldwide, including Brazilian Professor Wilson Engelmann, elaborated a document on the "Research Priorities Relevant to Development or Updating of Nano-relevant Regulations and Guidelines". In this document it was proposed to use a flexible diagram that would accept updates as knowledge is acquired and issues undergo adjustments (STONE, 2017).

It is credible that the form of technology will not always be new, but it will constantly change the circumstances, problems and solutions, and this will involve legal and regulatory questions (BENNETT MOSES, 2013). That is why specific laws are sometimes desirable for technology. There is nothing illogical in discussing specific legislation for technology, but it only makes sense to introduce it if the 
regulating logic is closely linked to the technology itself (BENNETT MOSES, 2013). Therefore regulatory measures should be dynamic in order to follow the evolution of scientific knowledge and generate safety.

In Luhmann's view - which is the theoretical frame of reference of this article -, although law is seen as a structure, it is dynamic due to the permanent evolution provoked by its need to constantly act as one of the social structures that reduce the complexity of the possibilities of being in the world (ROCHA, 2007, p.51). Based on this reasoning, legal research should be directed at a new concept of society, focused on postulates such as risks and paradoxes. A different system must be at the same time operationally closed to maintain its unity and cognitively open to observe its constitutive difference (ROCHA, 2008, p.52).

In this respect, sociology of knowledge is guided by its temporal dimension of responsibility. Therefore, the regulation of innovation is the regulation of the knowledge that represents a given form of regulation of the future, forms of social construction of the future (BORA, 2012, p.127-145).

It must be underscored and assumed therefore that the objective of technological regulation is laborious and complex. A lot depends on how one defines "technology". One approach is to visualize a network that will include actors (including politicians and engineers) and objects (products) that influence each other (BENNETT MOSES, 2013).

This regulation and, consequently, responsibility present themselves as a decision in the temporal structure (BORA, 2012, p.127-145). In this sense, regulation can even use Luhmann's communicative construction, in a given space and time, according to which society is made up of various functionally differentiated systems that are connected by communication. The limits of society are the limits of communication, and it is no longer possible to isolate oneself within society; because of communication, modern society is a global society (LUHMANN, 2007, p.69-70).

Obviously, sanctions do not diminish the risk, but produce an effect on the legal system through externalization of the risk (BORA, 2012, p.127-145). In this sense, the responsibility for innovation is one among many forms of guidance for the 
future and a mechanism for social attribution and attribution of the blame of risk to the actors (BORA, 2012, p.127-145).

A factor that makes it difficult to approach regulation is the paradox of uncertainty. In this scenario, even without sufficient information about the risks, it is necessary to make a decision (BENNETT MOSES, 2013). An alternative that arises is to encourage flexible regulation, founded on "soft law", which is useful in this scenario especially when the "political decision-makers" are not certain about the social or economic impact of the rules. Thus, progress in knowledge of technology can be connected to the reduction of uncertainties over time (ABBOTT; MARCHANT; SYLVESTER, 2009).

In the case of nanotechnology, the risks are closely related to the risks associated with other chemical substances and manufacturing methods. They are different in terms of details (where nano-silver has different properties from standard silver), but they are not different in terms of kind. Laws would thus need to acknowledge that the size of particles (among other things) may affect the properties and that the risks are still being investigated (the unknown ones), but need to be managed (BENNETT MOSES, 2013).

A "nanolaw" might solve the problems identified today, but would only have specific solutions which would be of short duration. Therefore it is clearly necessary to think broadly about the regulation of new materials involving risks that are as yet unknown (BENNETT MOSES, 2013). A risk management mechanism that can be easily adapted when a new nanotechnology is discovered must be developed, a "risk management system" that accepts to include the new scientific discoveries in the calculation of acceptability of risk and precautionary decisions.

The tendency is to make conservative estimates (generally based only on premises) which may result in an excessive risk management, which would impair the development of nanoproducts. In order to avoid this, it is essential to assess uncertainty, because this may significantly improve communication of risk and make it more realistic (STONE, 2017). 
Considering the scientific uncertainty of the positive and negative effects of this technology, it is important to mention management that uses the precautionary principle. Charles Vlek, in this sense, describes 10 questions to be applied under these circumstances in order to appropriate knowledge and induce decision-making regarding risks:

1. General inclination and motivation ('Why precaution?'); 2. Nature and seriousness of potential harm (e.g. 'Worst case?'); 3. Plausibility of possible harm or damage; 4. Precautionary decision-making: balancing over- vs under-protection; 5. Precautionary safety actions ('What could we do, provisionally?'); 6 . Optional versus obligatory precaution; 7 . Who carries the burden of proof of risk or safety?; 8. Further research and policy development; 9. Multiparty communication and deliberation; 10 . Distribution of responsibilities ('Who should do what, and when?') (VLEK, 2009).

The Precautionary Principle applies when people ... are confronted with a situation of serious uncertain risk or threat. It involves: an analysis and evaluation of credible worst-case scenarios; the making of epistemic judgments on the basis of incomplete evidence; the inclination to take a cautious or 'pessimistic' decision about a provisional course of action; a careful evaluation of expected costs, risks, and benefits of the target activity and its feasible alternatives; and the timely selection and implementation of 'reasonable' precautionary ... measures (VLEK, 2009).

A broad legislation could be drafted, founded on the precaution against unknown risks and the prevention of known ones, aiming, through scientists' experiences, to gradually introduce information and ways to verify acceptable and non-acceptable risks. A zero risk society is impossible. Therefore it is necessary to deal with risk even when confronted with uncertainties in order to avoid as much as possible repeating the disastrous scenes that have been seen and borne worldwide.

\section{CONCLUSION}

In the present article, initially the concept of nanotechnological risks and evidence that these risks may involve harmful effects both to the environment and to human beings were discussed. It was found that technology, since the Industrial Revolution, has always emerged to make the life of society easier, but that, since the 
beginning, the investments always prioritized only development from the economic angle, rather than the prevention if potential damage.

It is important to realize that even if no environmental disaster resulting from nanotechnology occurs, scientific knowledge has already proved that chemical elements on a nanoscale have completely distinct properties that are thus, not known in their totality. Therefore, in the environment the effects have a greater permeability, capacity for dispersion, persistence, adsorption and interaction, generating seriously alarming effects. Ergo there is a clear and emerging need for regulation in the international and national sphere.

At the same time, this absence of regulation provides the opportunity for an approach that is as innovative as the technology itself. The purpose of this approach should be the safe development of this fascinating technology for the environment and for human beings.

The problem proposed in this article involves the risks of nanotechnology, its uncertainties regarding damage to the environment and human beings, and therefore the need for international and national regulation. Based on this problem, the hypotheses for a solution were developed and confirmed.

As a conclusion initially regulation should begin with international coordination, considering the growing recognition of the global market. This harmonized commitment would make trade easier, prevent disputes and frustrating experiences, enable the elaboration of internationally consistent standards that would protect against an inordinate race, uncertainty, risks and consequently damage. It was shown that some paths to an international design have already been proposed in different ways and all are plausible considering the regulatory void that generates many insecurities for all stakeholders.

However, even with an international approach there is still need for an argument founded on the supreme protection of the environment and of human beings as "values in themselves". In this way, this international regulatory need was connected to the human rights, under the strong influence and international safety that must be considered. It was thus argued that natural rights, human rights and 
fundamental rights are part of the same category of rights, namely, the protection of human beings considering their pre-existing values. In the same sense, the environment is an element that is necessary to maintain human life and therefore it is interpreted in the extension of human rights.

Moreover, the damaging events already experienced by human beings and by the environment, be it from the bombs used in the Second World War or the environmental disasters that have occurred, should teach us a lesson. Learnings have shown the destructive capacity of the damage, its transtemporality and, especially related to globalization, its transborder characteristic. Therefore, all these elements justify the need to draft an international agreement on the safety of advances in research, development, manufacturing, trade and environmentally adequate final disposal of the products containing nanotechnology.

A broad legislation/regulation/principle, founded on precaution regarding the unknown risks and on the prevention of known ones, thus starting from an "international framework agreement" founded on human rights and on an ethic of technologies, expanding to an understanding of environmental protection, thus resulting in the protection against the environmental and human risks of nanotechnology.

This regulation must be dynamic, connected to the current technological context (that is "the challenge of regulatory connection"). The form of technology will not always be new, but the circumstances, problems and solutions will change constantly and will require legal and regulatory measures.

Therefore, to enable the regulation to keep up with technology, mechanisms are required that will accept the necessary and dynamic adaptations in the course of the development of nanotechnology. One of these mechanisms might be risk management with the possibility of inserting scientific information to assess the risks compared to their acceptability as they are discovered. 


\section{REFERENCES}

ABBOTT, Kenneth; MARCHANT, Gary; SYLVESTER, Douglas. Transnational Regulation of Nanotechnology: Reality or Romanticism? International Handbook on Regulating Nanotechnologies, Edward Elgar. 2009. Available at: <https://ssrn.com/abstract=1424697>. Retrieved on: 21 July 2017.

ALVES, Oswaldo. Nanotecnologia, nanociência e nanomateriais: quando a distância entre presente e futuro não é apenas questão de tempo. Revista Parcerias Estratégicas, Brasília, n. 18, 2004.

BARRETTO, Vicente de Paulo. O "admirável mundo novo" e a teoria da responsabilidade. IN: TEPEDINO, Gustavo; FACHIN, Luiz Edson (Coords.). 0 Direito e o Tempo: embates jurídicos e utopias contemporâneas. Estudos em homenagem ao Professor Ricardo Pereira Lira. Rio de Janeiro: Renovar, 2008.

BENNETT MOSES, Lyria. How to Think about Law, Regulation and Technology: Problems with 'Technology' as a Regulatory Target. Law, Innovation and Technology. 2013. Available at: <https://ssrn.com/abstract=2464750>. Retrieved on: 19 July 2017.

BERWIG, Juliane Altmann; ENGELMANN, Wilson. A matriz teórica jurídica dos desastres ambientais no ciclo de geração de energia na sociedade sistêmica. Revista Quaestio luris, vol. 10, ㄲo. 02, Rio de Janeiro, 2017. pp. 615-634. Available at: $\quad<h t t p: / / w w w . e-p u b l i c a c o e s . u e r j . b r / i n d e x . p h p / q u a e s t i o i u r i s / a r t i c l e / v i e w / 22998>$.. Retrieved on: 22 July 2017.

BORA, Alfons. Capacidade de lidar com o futuro e responsabilidade por inovações para o trato social com a temporalidade complexa. In: SCHARTZ, Germano (Org.). Juridicização das Esferas Sociais e Fragmentação do Direito na Sociedade Contemporânea. Porto Alegre: Livraria do Advogado, 2012.

BRASIL. Decreto № 591, de 6 de julho de 1992. Atos Internacionais. Pacto Internacional sobre Direitos Econômicos, Sociais e Culturais. Promulgação. Available at: <http://www.planalto.gov.br/ccivil_03/decreto/1990-1994/d0591.htm>. Retrieved on: 22 July 2017.

BRASIL. MINISTÉRIO DA CIÊNCIA, TECNOLOGIA, INOVAÇÃO E COMUNICAÇÕES. Projeto Nanoreg. Available at: <http://www.mcti.gov.br/projetonanoreg>. Retrieved on: 23 July 2017.

BROWNSWORD, Roger; YEUNG, Karen. Regulating Technologies: Legal Futures, Regulatory Frames and Technological Fixes. Hart Publishing, 2008. Available at: <https://books.google.com.br/books?id=Z jbBAAAQBA $\mathrm{J} \& p g=P P 3 \& \mathrm{hl}=\mathrm{pt}-\mathrm{BR} \&$ source=gbs_selected_pages\&cad=2\#v=onepage\&q\&f=false> . Retrieved on: 22 July 2017. 
CIÊNCIA HOJE. A equação e a bomba atômica. Available at: $<$ http://www.cienciahoje.org.br/noticia/v/ler/id/2724/n/a_equacao_e_a_bomba_atomic a>. Retrieved on: 19 July 2017.

CORDIS. International Dialogue. Available at: <https://cordis.europa.eu/nanotechnology/src/intldialogue.htm>. Retrieved on: 21 July 2017.

CORDIS. Third international dialogue on responsible research and development of nanotechnology. Available at: $<$ https://cordis.europa.eu/pub/nanotechnology/docs/report_3006.pdf>. Retrieved on: 21 July 2017.

DE GIORGI, Raffaele. O risco na sociedade contemporânea. Revista Sequência. n. 28, ano 15, junho, 1994 . p. 45-54. Available at: $<$ http://www.egov.ufsc.br/portal/conteudo/o-risco-na-sociedadecontempor\%C3\%A2nea>. Retrieved on: 19 July 2017.

DIREITOS HUMANOS. Declaração sobre o uso e o progresso científico e tecnológico no interesse da Paz e em benefício da Humanidade. 1975. Available at: <http://www.dhnet.org.br/direitos/sip/onu/bmestar/dec75.htm>. Retrieved on: 22 July 2017.

ENGELMANN, Wilson. As nanotecnologias e a gestão transdisciplinar da inovação. In: ENGELMANN, Wilson (org.). As novas tecnologias e os direitos humanos: os desafios e as possibilidades para construir uma perspectiva transdisciplinar. Curitiba: Honoris Causa, 2011.

. As nanotecnologias e a inovação tecnológica: a "hélice quádrupla" e os direitos humanos. In: Anais do Seminário Nanotecnologias: um desafio para o Século XXI. Blog JUSNANO, São Leopoldo, 2010. Available at: <http://jusnano.blogspot.com.br/>. Retrieved on: 31 July 2017.

O diálogo entre as fontes do direito e a gestão do risco empresarial gerado pelas nanotecnologias: construindo as bases à juridicização do risco. In: STRECK, (Org.); Lenio Luiz; ROCHA, Leonel Severo. Constituição, Sistemas Sociais e Hermenêutica, Anuário do Programa de Pós Graduação em Direito da UNISINOS. Porto Alegre: Livraria do Advogado, v. 9, 2012.

; FLORES, André Stringhi; WEYERMÜLLER, André Rafael. Nanotecnologias, Marcos Regulatórios e Direito Ambiental. Curitiba: Honoris Causa, 2010.

; WILLIG, Júnior Roberto. Inovação no Brasil: entre os riscos e o marco regulatório. Jundiaí: Paco Editorial, 2016. 
FAUNCE, Thomas Alured. Nanotechnology in Global Medicine and Human Biosecurity: Private Interests, Policy Dilemmas and the Calibration of Public Health Law (December 18, 2007). Journal of Law, Medicine and Ethics (US), Vol. 35, No. 4, pp. 629-642. Available at: <https://ssrn.com/abstract=1406302>. Retrieved on: 19 July 2017.

FIORINO, Daniel J. Voluntary initiatives, regulation, and nanotechnologies oversight: charting a path. Project for Emerging Nanotechnologies, n. 19, nov. 2010. Available at: <http://www.nanotechproject.org/process/assets/files/8347/pen-19.pdf>. Retrieved on: 19 July2017.

GUZMÁN, Katherine A.; TAYLOR, Margaret R.; BANFIELD, Jillian F. Environmental risks of nanotechnology: National nanotechnology initiative funding. Environ. Sci. Technol., 40(5):1401-1407, 2006. Available at: <http://pubs.acs.org/doi/pdf/10.1021/es0515708>. Retrieved on: 05 July 2016.

JONAS, Hans. O princípio responsabilidade: ensaio de uma ética para a civilização tecnológica. 1979. Translation by Marijane Lisboa and Luiz Barros Montez. Rio de Janeiro: Puc, s.d..

LUHMANN, Niklas. La sociedad de la sociedad. Translation by Javier Torres Nafarrete. México: Herder/Universidad Iberoamericana, 2007.

$\overline{\text { Editorial, }} 2005$.

El concepto de riesgo. México: Universidad Iberoamericana/Herder

MERIDIAN INSTITUTE. International Dialogue on Responsible Research and Development of Nanotechnology. Available at: $<$ http://merid.org/en/Content/Projects/International_Dialogue_on_Responsible_resear ch_and_Development_of_Nanotechnology.aspx>. Retrieved on: 21 July 2017.

NANOREG. A common European approach to the regulatory testing of nanomaterials. 2017a. Available at: <http://www.nanoreg.eu/project/nanoregobjectives >. Retrieved on: 23 July 2017.

Final Report. $2015 . \quad$ Available at: <http://www.rivm.nl/en/About_RIVM/International_Affairs/International_Projects/Com pleted/NANoREG/NANoREG_Results_Repository_sub_page_Final_Report/NANoRE G_Final_Report_Part_1.pdf>. Retrieved on: 23 July 2017.

2017b. Available
<http://publications.jrc.ec.europa.eu/repository/bitstream/JRC105651/kjna28550enn.

NANoREG framework for the safety assessment of nanomaterials.

pdf>. Retrieved on: 23 July 2017. 
ONU - ORGANIZAÇÃO DAS NAÇÕES UNIDAS. Declaração Universal dos Direitos Humanos. $2014 . \quad$ Available <http://www.onu.org.br/img/2014/09/DUDH.pdf>. Retrieved on: 19 July 2017.

PYRRHOI, Monique; SCHRAMM, Fermin Roland. A moralidade da nanotecnologia. In: Cadernos de Saúde Pública, Rio de Janeiro, v. 28, n. 11, nov. 2012.

ROCHA, Leonel Severo. Notas sobre Niklas Luhmann. In: Revista de Estudos Jurídicos. São Leopoldo: Centro de Ciências Jurídicas - UNISINOS, 2007.

SHEARER, Cameron. A guide to the nanotechnology used in the average home. Available at: <http://www.nanowerk.com/spotlight/spotid=43847.php>. Retrieved on: 05 April 2017.

STONE, Vicki et al. Research priorities relevant to development or updating of nano-relevant regulations and guidelines. Available at: $<$ http://www.safenano.org/news/news-articles/eu-nanosafety-cluster-publishesresearch-regulatory-roadmap>. Retrieved on: 30 July 2017.

SYLVESTER, Douglas; ABBOTT, Kenneth; MARCHANT, Gary. Not Again! Public Perception, Regulation, and Nanotechnology. Regulation and Governance, 2009. Available at: <https://ssrn.com/abstract=1309743>. Retrieved on: 21 July 2017.

UNESCO. Declaração Universal sobre Bioética e Direitos Humanos. 2001. Available at: <http://unesdoc.unesco.org/images/0014/001461/146180por.pdf>. Retrieved on: 22 July 2017.

VLEK, Charles. A Precautionary-Principled Approach towards Uncertain Risks: Review and Decision-Theoretic Elaboration. Erasmus Law Review, Vol. 2, N. 2, 2009. Available at: https://ssrn.com/abstract=1498431 >. Retrieved on: 21 July 2017. 